\title{
PENERAPAN MANAJEMEN STRATEGI DALAM PENINGKATAN MUTU MADRASAH
}

\author{
JAMALUDDIN ISKANDAR \\ Fakultas Tarbiyah dan Keguruan, UIN Alauddin Makassar \\ JI. HM. Yasin Limpo No. 36 Makassar \\ Email: jamaluddiniskandar@yahoo.co.id
}

\begin{abstract}
:
Strategic management is an improvement in the quality of education that has long been applied for the achievement of a predetermined educational goal, which is based on the Act has been determined. Implementation of strategic management includes external internal analysis, and samapai at strategic evaluation stage to find out how far the results have been achieved. In addition, it must be supported by various things including adequate facilities, community support and the surrounding government. Improving the Quality of Education includes the processes and outcomes of education that affect each other. In measuring a certain quality of education if it can be known by looking at various things, among them is the maximum learning process, adequate facilities, professional teachers with various capabilities possessed, to the support of various parties. Based on the results of the discussion, it can be seen that there is a significant influence between the implementation of strategic management with improving the quality of education in all levels of education.
\end{abstract}

Keywords: Strategic Management, Quality, Madrasah

\section{PENDAHULUAN}

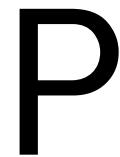

endidikan pada sebagian besar jenjang dan satuan pendidikan, khususnya pendidikan dasar dan menengah. dipandang bermutu jika mampu melahirkan keunggulan akademik dan ekstrakurikuler pada peserta didik yang dinyatakan lulus untuk satu jenjang pendidikan atau menyelesaikan program pembelajaran tertentu

Mengenai masalah mutu pendidikan dapat dilihat dalam dua hal, yakni mengacu pada proses pendidikan dan hasil pendidikan. Proses pendidikan yang bermutu apabila seluruh komponen pendidikan terlibat dalam proses pendidikan itu sendiri. Faktor-faktor dalam proses pendidikan adalah berbagai input, seperti bahan ajar, metodologi, sarana sekolah, dukungan administrasi dan sarana dan prasarana dan sember daya lainnya serta penciptaan suasana yang kondusif. Untuk menjalankan pendidikan dengan berbagai komponen tersebut seyogyanya dibutuhkan manajemen sebagai pengarahan sekaligus bahan penggerak dalam menjalankan pendidikan. Sementara mutu pendidikan dalam konteks hasil pendidikan mengacu pada prestasi yang dicapai atau hasil yang dicapai oleh sekolah pada setiap kurung waktu tertentu. 
Berbagai usaha telah diupayakan untuk meningkatkan mutu pendidikan nasioanl, antara lain melalui berbagai pelatihan dan peningkatan kompetensi guru, pengadaan buku dan alat pelajaran, perbaikan sarana dan prasarana pendidikan dan sampai kepada peningkatan mutu manajemen sekolah. Namun demikian, berbagai indikator mutu pendidikan belum menunjukan peningkatan yang signifikan.

Manajemen stratejik merupakan suatu alternatif yang seyogyanya dapat menjadi jalan keluar dari berbagai permasalahan yang membelut dunia pendidikan di Indonesia saat ini. Setiap organisasi (sekolah) dihadapkan kepada dua jenis "lingkungan", yaitu lingkungan internal dan lingkungan eksternal. Makin besar suatu organisasi, makin kompleks pula bentuk, jenis dan sifat bentuk interaksi yang terjadi dalam menghadapi kedua jenis "lingkungan" tersebut. Salah satu implikasi kompleksitas itu ialah proses pengambilan keputusan yang semakin sulit dan rumit. Untuk itu dibutuhkan manajemen stratejik (Siagian, 2012: 1). Pengertian strategi itu sendiri dapat diartikan sebagai sebuah rencana yang komprehensif mengintegrasikan segala resources dan capabilities yang mempunyai tujuan jangka panjang untuk memenangkan kompetisi (Sagala, 2010: 137).

Oleh sebab itu, strategi merupakan instrumen manajemen yang ampuh dan tidak dapat dihindari termasuk dalam manajemen sekolah. Strategi sekolah menjelasakan tentang metode dan pendekatan yang digunakan untuk mencapai tujuan strategiknya. Untuk mencapai tujuan sekolah, evaluasi alternatif-alternatif stratejik dengan menggunakan kriteria yang pasti dan pemilihan sabuah alternatif atau kelompok yang mungkin menjadi strategi sekolah.

Penyelenggaraan menejemen stratejik harus mampu menjamin kualitas kinerjanya. Dengan demikian, manajemen stratejik dituntut untuk menjaga konsistensi antara visi, misi, tujuan dan sasaran yang bepedoman pada rencana strategis sekolah. Penerapan manajemen stratejik, sekolah akan memilki keputusan yang tepat untuk mencapai rencana yang nantinya bermuara kepada tujuan sekolah.

Berangkat dari itu, efektifitas pelaksanaan manajemen strategi di Madrasah dapat tercapai apabila pengelolaan pendidikan tertata dengan baik dan terarah, melalui kerja sama antara manajemen puncak dalam hal ini kepala sekolah, para guru dan staf, dukungan masyarakat, serta perhatian pemerintah. Sehingga penerapan manajemen stratejik dapat berjalan secara maksimal dan sesuai yang diharapkan, karena keseluruhan proses pendidikan di sekolah tergantung dari bagaimana pengelolaannya. Ini berarti bahwa salah satu tolok ukur berhasil tidaknya pencapaian tujuan pendidikan di suatu sekolah ditentukan dari bagaimana proses pengelolaannya.

Berdasarkan pernyataan tersebut, maka penulis merumuskan masalah sebagai berikut:

1. Bagaimana penerapan panajemen stratejik di Madrasah 
2. Apakah penerapan manajemen stratejik berpengaruh signifikan terhadap peningkatkan mutu pendidikan di Madrasah

\section{TINJAUAN TEORITIS}

\section{Manajemen Stratejik}

\section{Pengertian Manajemen Stratejik}

Organisasi harus memilki strategi dalam pencapaian suatu tujuan. Strategi disusun dengan perencanaan-perencanaan organisasi dengan tahapan berupa analisis lingkungan internal dan eksternal. Sebelum membahas lebih lanjut tentang pengertian manajemen stratejik, terlebih dahulu penulis menjabarkan pengertian manajemen dan stratejik itu sendiri.

Rosyada menegaskan bahwa kurikulum itu adalah perencanaan yang ditawarkan, bukan yang diberikan, karena pengalamn yang diberikan guru belum tentu ditawarkan. Dengan demikian seluruh konsep pendidikan di sekolah itu harus eideal. Kurikulum harus berbicara tentang keharusan bukan kemungkinan (Rosyada, 2007: 26).

Dari beberapa pengertian di atas, penulis dapat menyimpulkan bahwa kurikulum adalah seperangkat rencana dan pengaturan mengenai keseluruhan tatanan pendidikan seperti tujuan, isi dan bahan ajar yang menjadi pedoman dalam pelaksanaan pembelajaran dan proses pencapaian tujuan pendidikan atau sekolah yang diaktualisasikan di kelas maupun diluar kelas sebagai pengalaman murid serta kumpulan mata pelajaran yang diajarkan kepada siswa agar tujuan pendidikan dapat tercapai.

\section{Upaya Meningkatkan Mutu Pendidikan}

Upaya meningkatkan mutu pendidikan di sekolah memerlukan titik berangkat dari pola pemikiran yang memandang sekolah sebagai suatu sistem. Sekolah terdiri dari berbagai komponen yang saling berhubungan, membutuhakan dan saling berinteraksi antara satu dengan yang lainnya.

Malalui penggarapan seluruh komponen sekolah, pendidikan bermutu tinggi apabila setiap anak didik berkembang secara optimal sesuai kemampuannya serta dapat mengembangkan kemampuan dan keahlian bagi bagi peningkatan mutu pendidikan. Pendidikan yang bermutu tinggi akan mengantarkan anak didik ke arah pembentukan manusia Indonesia seutuhnya. Dalam peningkatan mutu pendidikan, ada beberapa metode yang digunakan dalam peningkatan mutu pendidikan adalah manajemen mutu terpadu atau yang biasa disebut Total Quality Manajemen (TQM).

Menurut Bounds yang dikutip oleh E. Mulyasa mengeluarkan pendapat bahwa "Manajemen mutu terpadu adalah suatu sistem manajemen yang berfokus kepada orang yang bertujuan untuk meningkatkan secara berkelanjutan kepuasan pelanggan (customers) pada biaya sesungguhnya secara berkelanjutan terus menerus" (Mulyasa, 2003: 224). 
Sementara Mulyadi berpendapat bahwa TQM merupakan pendekatan sistem secara menyeluruh (bukan suatu bidang atau program terpisah) dan merupakan bagian terpadu strategi tingkat tinggi. Sistem ini bekerja secara horizontal manembus fungsi dan departemen, melibatkan semua karyawan dari atassampai bawah, meluas ke hulu dan ke hilir, dan mencakup mata rantai pemasok customer (Mulyasa, 2003: 224).

Sedangkan E. Mulyasa "sekolah yang bermutu tidak hanya dilihat dari mutu lulusannya, tetapi juga mencakup bagaimana lembaga pendidikan mampu memenuhi kebutuhan pelanggan sesuai dengan standarmutu yang berlaku.

Menurut Green Wood dalam Rosyada dikatakan bahwa pelanggan pendidikan adalah sebagai berikut:

a. Siswa-siswa yang memperoleh pelajaran

b. Orang tua siswa yang membayar baik langsung maupun tidak langsung untuk biaya pendidikan anak-anaknya,

c. Pendidikan lanjut atau institusi pendidikan tempat siswa melanjutkan studi.

d. Para pemakai tenaga kerja yang perlu untuk merekrut staf terampil, memiliki keahlian dan kependidikan sesuai kebutuhan.

e. Negara yang memerlukan tenaga terdidik dengan baik (Rosyada, 2007: 270).

Adapun usaha yang dilakukan kepada sekolah guna meningkatkan mutu pendidikan adalah dengan menciptakan suasana kerja yang menyenangkan, aman dan menantang. Usaha ini akan membawa dampak yang positif bagi tumbuhnya sikap terbuka dari guru-guru, guru-guru juga harus didorong agar kreatif serta memilki kinerja yang tinggi. Tinggi rendahnya mutu dari suatu pendidikan (sekolah) dapat dilihat dari bagaimana bagaimana kinerja seorang manajer puncak (kepala sekolah) dalam mengelola sekolahnya.

\section{PEMBAHASAN}

\section{Gambaran Manajemen Strategik di Madrasah}

Dalam meningkatkan mutu pendidikan di Madrasah tak lepas dari yang namanya manajemen stratejik, yaitu suatu pendekatan yang sistematis bagi suatu tanggung jawab manajemen, mengondisikan organisai ke posisi yang dipastikan mencapai perusahaan (sekolah) menjamin atau mengamankan format yang mengejutkan. Pendekatan sistematis untuk melakukan perubahan menjadi hal penting dalam manajemen stratejik, dan melalui pendekatan manajemen stratejik harus dipastikan bahwa tujuan akan dicapai.

Sehubungan dengan pembahasan sebelumnya bahwa yang menjadi indikator penerapan manajemen stratejik adalah dengan melihat konsep dari manajemen stratejik itu sendiri, mulai dari nalisis lingkungan eksternal dan internal, formulasi strategi, implementasi strategi, dan sampai pada tahap evaluasi stretegi, dengan 
demikian kita akan dapat mengetahui bagaimana penerapan manajemen strategi dalam meningkatkan mutu pendidikan dengan berbagaia indikator.

\section{Penerapan Manajemen Stratejik dalam Meningkatkan Mutu Pendidikan di Madrasah}

Diduga penerapan manajemen stratejik dan peningkatan mutu pendidikan.sangat jelas keberadaanya sehingga dalam meningkatkan mutu pendidikan di madarasah diperlukan menejmen secara stratejik sangat dibutuhkan keberadaannyyaa. Karna pendidikan membutuhkan manejemen secara stra tegik dilaksanakan.

Dari penjelasan pendapat di atas penulis dapat menarik kesimpulan bahwa pada pada hakikatnya dimensi adalah inti dari menajemen stratejik, di mana manajemen stratejik diharuskan mengambil keputusan sesuai dengan wewenag dari menejemen puncak, dari keputusan itu sendiri berpusat dari analisis enternal dan eksternal organisasi atau sekolah.

Dalam konteks pendidikan, sekolah itu berkualitas jika mampu melaksanakan proses pembelajaran yang sesuai dengan rancangan-rancangan yang ditetapkan bersama antara sekolah dan komite sekolah, mencapai terget sesuai yang direncanakan, serta sesuai pula dengan harapan orang tua siswa, pemerintah, siswa, para pengguna lulusan baik sekolah atau perguruan tinggi tempat siswa melanjutkan studinya, maupun dunia kerja.

\section{PENUTUP}

Berdasarkan hasil analisis data dan pembahasan yang telah dijelaskan sebelumnya, maka penulis dapat menarik kesimpulan sebagai berikut:

1. Manajemen strategik merupakan peningkatan kualitas pendidikan yang sudah lama diterapkan demi tercapainya suatu tujuan pendidikan yang telah ditetapkan, yang berlandaskan pada UU telah ditentukan. Penerapan manajemen stratejik meliputi analisis internal eksternal, dan samapai pada tahap evaluasi stratejik untuk mengetahui sejauh mana hasil yang telah dicapai. Di samping itu, harus ditopang dengan berbagai hal di antaranya adalah fasilitas yang memadai, dukungan masyarakat dan pemerintah sekitar.

2. Peningkatan Mutu Pendidikan meliputi proses dan hasil pendidikan yang saling mempengaruhi. Dalam mengukur suatu mutu pendidikan tertentu sekiranya dapat diketahui dengan melihat berbagai hal, di antaranya adalah proses pembelajaran yang maksimal, fasilitas yang memadai, guru yang professional dengan berbagai kemampuan yang dimiliki, sampai pada dukungan dari berbagai pihak.

3. Berdasarkan hasil pembahasan, maka dapat diketahui bahwa adanya pengaruh yang signifikan antara penerapan manajemen stratejik dengan peningkatan mutu pendidikan di semua jenjang pendidikan. 


\section{DAFTAR PUSTAKA}

Amri, Sofyan. Peningkatan Mutu Pendidikan Sekolah Dasar dan Menengah, dalam Teori, Konsep dan Analisis. Jakarta: Prestasi Pustakaraya, 2013.

Anas, Sudijono. Pengantar Statistik Pendidikan. Cet XXII; Jakarta: PT RajaGrafindo Persada, 2009.

Arif, Armai. Reformasi Pendidikan Islam. Jakarta: CRSD Press, 2004.

Arifin, H. Muzyim. Kapita Selekta Pendidikan Islam. Jakarta: PT. Bumi Aksara, 2003.

Danim, Sudarwan. Otonomi Manajemen Sekolah. Bandung: Alfabeta, 2010.

Departemen Agama Ri, Al-Quran dan Terjemahan. Jakarta: Syamil Media Cipta, 2010.

Fahmi, Irham. Manajemen Teori, Kasus, dan Solusi. Bandung: Alfabeta, 2012.

Hamid, Darmadi. Metode Penelitian Pendidikan. Cet. II; Bandung: Alfabeta, 2011.

Hariadi, Bambang. Manajemen memenangkan perang bisnis. Malang: Bayumedia Publising, 2005.

Hassel, Nogi S.Tangkilisan. Manajmen Moderen Untuk Sektor Public. Yogyakarta: Balairung, 2003.

Iqbal, M. Hasan. Pokok-pokok Materi Statistik 1. Cet. IV; Jakarta:Bumi Aksara, 2008.

Iqbal, M. Hasan. Pokok-Pokok Materi Statistik 2 (Statistik Inferensif). Cet. II; Jakarta:Bumi Aksara, 2001.

Iskandar. Psikologi Pendidikan. Cet I; Jakarta: Gaung Persada Press, 2009.

Kasidi. Manajemen Risiko. Bogor: Ghalia Indonesia, 2010.

Kuncoro, Mudrajat, Strategi Bagaimana Meraih Keunggulan Kompetitif. Jakarta: Erlangga, 2005.

Mulyasa, E. Menjadi kepala Sekolah Profesional dalam Konteks Menyukseskan MBS dan KBK. Bandung: PT Remaja Rosada Karya, 2003.

Musfiqon. Metodologi Penelitian Pendidikan. Cet. 1; Jakarta: Prestasi Pustaka Publisher, 2012.

Muslich, Mansur. KTSP(Kurikulum Tingkat Satuan Pendidikan) Dasar Pemahaman dan Pengembangan. Jakarta: PT.Bumi Aksara, 2009.

Natsir, Moh. Metode Penelitian. Cet III; Jakarta :Ghalia Indonesia, 1988.

Nawawi Hadari. Manajemen Strtategik Organisasi Non Profit Bidang Bisnis Pemerintahan dengan Ilustrasi di Bidang Pendidikan. Yogyakarta: Gadja Mada University Press, 2005.

Nawawi, Hadari. Manajemen Strategik Organisasi Non Profit Bidang Pemerintahan. Yogyakarta: UGM Press, 2000.

Ramayulis, H. IImu Pendidikan Islam. Jakarta: PT Kalam Mulia, 2004.

Republik Indonesia, Undang-Undang Dasar RI 1945, Cet. II; Jakarta: Sinar Grafika, 2009. 
Rosyada, Dede. Pradigma Pendidikan Demokrasi Sebuah Model Pelibatan Masyarakat dalam Penyelenggaraan Pendidikan. Jakarta: PT kencana Prenada Media Group, 2007.

Sadiman, Arief S. Dkk. Media pendidikan, pengertian, pengembangan, dan pemanfaatannya. Jakarta: PT Rajawali Pers, 2009.

Sagala, Syaiful. Manajemen Strategik dalam Miningkatkan Mutu Pendidikan, Bandung: Alfabeta, 2010.

Sondang P. Siagian. Manajemen Stratejik. Jakarta: PT Bumi Aksara, 2012.

Sugiyono. Metode Penelitian Kuantitatif, Kualitatif dan R\&D. Bandung : Alfabeta, 2011.

Sugiyono. Metode Penelitian pendidikan pendekatan kualitatif, kuantitatif dan R\&D. Bandung: Alfabeta, 2015.

Sugiyono. Statistik Untuk Penelitian. Bandung: Alfabeta, 2003.

Sugiyono. Statistik Untuk Penelitian. Bandung: PT. Alfabeta, 2010.

Suharsimi, arikunto. Dasar-dasar Evaluasi Pendidikan. Cet XI; Jakarta:Bumi Aksara, 2010.

Suharsimi, Arikunto. Prosedur Penelitian. Cet. XI; Jakarta: Rineka Cipta, 1998.

Suryabrata, Sumardi. Metodologi Penelitian. Edisi 1; Jakarta: PT Raja Grafindo Persada, 2009.

Thompson, Arthur A, Jr., John E. Gamble, A.J. Strickland III. Strategy Core Consepts Analytical Tool Readings. New York: McGraw-hill, 2006.

Yusanto, Ismail, Muhammad, dan Muhammad Karebet Widjajakususma. Manajemen Strategis Perspektif Syariah. Jakarta: Khairul Bayan, 2003. 